SERIE ETUDES ET DOCUMENTS DU CERDI

Beggar-thy-Neighbor Effects of Currency Undervaluation:

Is China the Tip of the Iceberg?

\title{
Samba MBAYE
}

Etudes et Documents $\mathrm{n}^{\circ} 39$

December 2012

\section{CERDI}

65 BD. F. MITTERRAND

63000 CLERMONT FERRAND - FRANCE

TEL. 0473717400

FAX 0473177428

www.cerdi.org 


\section{The author}

\section{Samba Mbaye}

PhD student

Clermont Université, Université d'Auvergne, CNRS, UMR 6587, CERDI, F-63009 Clermont Fd Email: Samba.Mbaye@udamail.fr

La série des Etudes et Documents du CERDI est consultable sur le site : http://www.cerdi.org/ed

Directeur de la publication: Patrick Plane

Directeur de la rédaction : Catherine Araujo Bonjean

Responsable d'édition : Annie Cohade

ISSN : 2114 - 7957

\section{Avertissement :}

Les commentaires et analyses développés n'engagent que leurs auteurs qui restent seuls responsables des erreurs et insuffisances. 


\begin{abstract}
This paper examines empirically one of the most popular views in international economics, yet barely tested: undervaluation of the currency is a "beggar-thy-neighbor" policy. It assesses simultaneously the two closely related implications of the beggar-thy-neighbor view: (i) undervaluation of the domestic currency improves the domestic trade balance; and most importantly, (ii) undervaluation of the domestic currency negatively impacts the other countries' trade balances. Starting from the traditional imperfect substitutes model, we propose an empirical framework allowing the estimation of both the internal and external impacts of currency undervaluation. This framework is then applied to a panel of 62 advanced and emerging markets over the period 1990-2007. The results give strong support to the beggar-thy-neighbor hypothesis. We find that currency undervaluation is robustly and significantly associated with an improvement of the domestic trade balance. We also find that countries that keep their currencies undervalued tend to negatively impact the other countries' trade balances. Finally, our estimates suggest that the external effect of China's renminbi, which has been the focus of the profession thus far, might be "the tip of the iceberg": the latter two results carry over when China's trade data are excluded from the analysis.
\end{abstract}

Keywords: exchange rate misalignment, trade, undervaluation, beggar-thy-neighbor, China

JEL Classification: F13, F42, O24

\title{
Acknowledgments
}

We are grateful to Mickaël Goujon, Bernard Hoekman, Olivier Cadot, Sylvianne Guillaumont Jeanneney, Patrick Plane, Samuel Guérineau, Armand Fouejieu and Florent Bresson for helpful comments. The usual disclaimer applies. 


\section{Introduction}

A common belief, deeply rooted in both academic and policy circles, is that undervaluation of the currency is a "beggar-thy-neighbor" policy, in that it simultaneously subsidizes domestic exports and curbs the foreign countries' exports. According to this view, currency undervaluation improves the trade balance of the country concerned, allowing the accumulation of trade surpluses, while dooming the other countries to trade deficits. The underlying idea is that exchange rate changes have substantial expenditure-switching effects, i.e., both exports and imports flows are sensitive to exchange rate movements. It is the belief in this idea that underpinned Paul Krugman (2010)'s famous column in The Financial Times pointing to the undervaluation of the renminbi as the cause of job losses in the United States. More generally, this has been the main argument motivating the "China bashing" on the international stage and in the media. Before China, Japan's exchange rate policy had been similarly incriminated for the large US trade deficit in the 1980s.

However, when one takes a closer look at the state of knowledge on this question, it appears that the popularity of this idea contrasts sharply with the lack of consensus among economists. The early wave of research in the new open economy macroeconomics has explored this issue by means of a clear welfare metric and the outcome is far from consensus. Alternative assumptions on price setting behaviors, the degree of substitutability between home and foreign goods, and the existence of intermediaries in the distribution chain, have alternatively led to the conclusion that a devaluation of the currency leads to "prosper-thy-neighbor / prosper-thy-self effects" (Obstfeld and Rogoff, 1995, 1996), "beggar-thy-self / prosper-thy-neighbor effects" (Corsetti and Pesenti, 2001), "prosper-thy-self / beggar-thy-neighbor effects" (Betts and Devereux, 2000), or both last two configurations depending on the ownership structure of importers (Tille, 2000).

Such controversies have been largely nourished by the paucity of empirical evidence on the external effect of currency undervaluation. There is an abundant literature on the impact of the latter on the domestic economy, but the empirical literature on the international dimension of exchange rate policy is rather sparse. ${ }^{1}$ Contributing to fill this gap is the aim of this paper. More specifically, we aim at exploring the role of real exchange rate undervaluation in the determination of trade balances across countries, by assessing the two closely related implications of the beggar-thy-neighbor view: (i) undervaluation of the domestic currency improves the domestic trade balance; and most importantly, (ii) undervaluation of the domestic currency negatively impacts the other countries' trade balances.

Beyond the intellectual and policy interest that these propositions could generate in their own right, two factors have recently rendered them of particular relevance. First, recent years have seen the

\footnotetext{
${ }^{1}$ The impact of undervaluation on the domestic economy has been examined through various aspects. See for example Rodrik (2008) and Nouira and Sekkat (2012) for competing views on the growth effect of undervaluation, Mbaye (2012) for its impact on productivity and Levy-Yeyati and Sturzenegger (2007) for empirical evidence on the exchange rate-investment relationship. See section 2 - and throughout the paper - for references on the trade impact of exchange rates.
} 
revival of what Obstfeld (2002) referred to as "exchange rate pessimism". Indeed, the view that exchange rate changes have limited impact on trade flows has been gaining supporters in recent years. Three main arguments are generally brought forth to justify such a belief: (i) a depreciation of the currency is not necessarily translated into corresponding price incentives, as the pass-through of exchange rate changes to import prices is known to be incomplete (see Gust et al., 2006; Betts and Devereux, 2000 among others), ${ }^{2}$ (ii) exporters could be left worse-off after a devaluation if they borrow in foreign currency or incur foreign-currency-denominated sunk costs when exporting (Berman and Berthou, 2009; Galindo et al., 2003 inter alia), and finally (iii) with the development of global supply chains and the implied interconnection between exports and imports, the trade balance response to exchange rate changes tends to be considerably reduced (Koopman et al., 2012; IMF, 2012). ${ }^{3}$ These findings have been backed up by somewhat mixed evidence on the impact of exchange rate changes on the domestic trade balance (see Rose and Yellen, 1989 for example). However, two things are worth mentioning here. First, these factors can mitigate the expected improvement of the trade balance following an undervaluation of the currency, but they are not likely to totally inhibit it. Second, as we shall argue below, the existing empirical literature has thus far missed an important point: in many cases, it is not the exchange rate movements that matter for the trade balance, but the lack of movements in these exchange rates. We will come back to this point in section 3 .

The second factor that motivated this research relates to the now well-known issue of "global imbalances" emerging, inter alia, in the form of large trade balance surpluses in some Asian countries -including China-, Germany, and oil-producing countries, as well as corresponding trade deficits in the United States and some developed countries. Several competing (but non-mutually exclusive) causes have been put forward to explain the build-up of these imbalances: asymmetries in financial development and growth prospects across different regions of the world (Caballero et al., 2008; Mendoza et al., 2008), the existence of a "global saving glut" (Bernanke, 2005), as well as asymmetries in saving behaviors across countries (see IMF, 2005 and Huang, 2010 among others). However, the most popular approach is arguably the "neo-mercantilism view" (Dooley et al., 2003) that interprets the rise in global imbalances as the by-product of explicit export promotion policies in several emerging markets, with China heading the list. By keeping their currency value low, these countries are accused of gaining, in Blanchard and Milesi-Ferretti (2011)'s words, an "unfair competitive advantage" over the other countries (p. 8). One important aspect in this view is the fact that exchange rate policy in one country is claimed to affect the other countries' trade balances. In this respect, we believe that the reported evidence in this paper could help inform the debate on the role of

\footnotetext{
${ }^{2}$ Note that even in the case of local-currency-pricing, that is zero pass-through, a depreciation still improves the domestic trade balance thanks to more favorable terms of trade.

${ }^{3}$ We focus our attention here on controversies on the expenditure-switching effect of exchange rate changes. A somewhat different view calling for pessimism about the beggar-thy-neighbor view, takes its starting point from the national accounting identity defining the trade balance as the difference between national savings and investment. Proponents of this view, such as Mckinnon (2010), contest the consistency of the beggar-thy-neighbor story on the grounds that it is silent on how exchange rate changes could be related to savings and investment. We will discuss this point in more detail in section 5
} 
currency undervaluation in the build-up of global imbalances, though it is clear that exchange rate policies are not the only cause of these imbalances.

Our empirical strategy is motivated by the following reasoning: if undervaluation of the currency is a beggar-thy-neighbor policy, as it is argued in China's case, one way to ascertain this claim is to look at what is going on for the other countries that exhibit undervaluation (as well as overvaluation) in their currencies. Such a strategy provides two advantages. First, it places the analysis in a general perspective and does not focus on individual cases that periodically come under the spotlight. Second, conclusions drawn from the study of China's only case can be hardly generalized, as China concentrates a mix of "specificities", such as capital control and a large proportion of state-owned enterprises participating in the export market, that make it hard to insulate the sole impact of its exchange rate policy. Accordingly, the analysis is conducted on bilateral trade balances between 62 advanced and emerging economies and their 10 largest partners over the period 1990-2007. We amend the traditional reduced form trade balance model à la Rose and Yellen (1989) in such a way that allows the estimation of both the internal and external trade impacts of currency undervaluation.

We find that undervaluation of the currency is robustly and significantly associated with an improvement of the domestic trade balance. Our estimates suggest that a $10 \%$ increase in the magnitude of undervaluation improves the domestic trade balance-to-GDP ratios by 0.4 to 0.8 percentage points on average. We also find that countries that keep their currencies undervalued tend to negatively impact the other countries' trade balances: a 10\% increase in the average undervaluation of partners' currencies worsens the home trade balances with these countries on average by 0.2 to 0.5 percentage points. Finally, our estimates suggest that the external effect of China's exchange rate policy, which has been the focus of the profession thus far, might be "the tip of the iceberg": the latter two results carry over when China's bilateral trade data are excluded from the sample.

This paper extends the existing literature on at least three points. First, to our knowledge, it is the first paper that quantifies the effect of currency undervaluation on the other countries' trade balances. Second, while existing papers on the external effect of exchange rate policy focused on China (Eichengreen and Tong, 2011 and Mattoo, et al., 2012), this paper favors a more systematic approach by exploiting the cross-national experience of a large set of economies. Third, we adopt a new empirical framework that helps us to prevent two of the main shortcomings of usual exchange ratetrade balance analyses: their failure to account for third-country effects as well as the impact of misalignments resulting from a lack of variability in real exchange rates (see section 3 ).

The remainder of this paper is organized as follows. The first two sections following this introduction respectively review previous empirical findings in the literature (section 2) and present our empirical framework (section 3). The latter is thereafter applied to our dataset described in section 4, including 
the undervaluation indexes used in this paper. Finally, section 5 reports the main findings before concluding.

\section{Overview of previous empirical findings}

Our paper straddles the line between two literatures: the voluminous empirical evidence on the domestic trade balance reaction to exchange rate changes and the incipient empirical literature on the external effects of exchange rate policy. The first of these literatures is an old one and has consequently been the object of countless papers. Nevertheless, one can identify two main streams of research in this vast number of studies. ${ }^{4}$ Early contributions, including Magee (1973), BahmaniOskooee (1985), Helkie and Hooper (1987), and Krugman and Baldwin (1987) inter alia, were interested in either estimating import and export trade elasticities to check the validity of the MarshallLerner condition or assessing the direct effect of exchange rate changes on the aggregate trade balance. The prevailing view at that time was that the trade balance responded positively to exchange rate depreciations and the dynamics of this response followed a (right-tilted) $\mathrm{J}$ curve; initially worsening in the short run before improving in the longer term.

However in the late 1980s, a new wave of papers called into question the validity of the latter view. Rose and Yellen (1989) were the first to highlight the methodological flaws present in previous studies, namely the use of aggregate multilateral trade data and the need for constructing a proxy for the rest of the world (ROW) income variable. They instead estimated a reduced form trade balance equation, using bilateral trade data between the US and its major partners, and reached dramatically different conclusions: there is neither a J-curve phenomenon nor statistical evidence that exchange rate movements affect the trade balance. Following these authors, subsequent research has since been oriented towards case studies, focusing on bilateral trade between individual countries and their major trade partners. These include, among others, Marwah and Klein (1996) for the US and Canada's cases; Bahmani-Oskooee and Goswami (2003) for Japan's case, as well as Wilson (2001) for Singapore, Malaysia and Korea's cases. A careful review of this literature is provided by Bahmani-Oskooee and Hegerty (2010). These authors conclude that empirical evidence on the exchange rate-domestic trade balance nexus are rather mixed.

Parallel to this traditional literature, our paper contributes to a nascent strand of empirical studies on the external effect of exchange rate policy. In fact, two recent papers have taken the same direction as this research. A first study by Eichengreen and Tong (2011) examined the effect of official announcements of future renminbi revaluations on foreign firms' stock-market valuations and found significant valuation effects depending on firms' relationships with Chinese firms, sectors and

\footnotetext{
${ }^{4}$ We restrict the discussion here to empirical papers on the exchange rate-trade balance relationship. Other related studies include the vast empirical literature on the exports reaction to exchange rate changes (Berman and Berthou, 2009; Fang et al., 2006 and Carranza et al., 2003 among others) which generally report small trade elasticities; the recent micro-evidence on the trade impact of exchange rates (Berman et al., 2012; Dekle and Ryoo, 2007; Forbes, 2002 inter alia); and papers on the trade effects of exchange rate volatility (see for example Chit et al., 2010).
} 
dependence on external finance. A second study by Mattoo et al., (2012) -probably the closest to ours- explores the effect of China's exchange rate policy on developing countries' exports in third markets, using disaggregated trade data at the 6-digit HS level. They find that renminbi appreciations/depreciations tend to boost/handicap the exports of countries that compete the more with China in third markets.

\section{Empirical framework}

We take our starting point from the usual workhorse of applied trade balance analysis: the "imperfect substitutes model" also known as the "Bickerdike-Robinson-Metzler model". This approach models the trade balance $(T B)$ as a function of the real exchange rate $(R E R)$ as well as domestic $(Y)$ and foreign outputs $\left(Y^{*}\right)$ :

$$
T B=T B\left(R E R, Y, Y^{*}\right)
$$

Following Rose and Yellen (1989), empirical studies usually estimate a log-linear variant of (1), using bilateral trade data. That is:

$$
(T B / Y)_{i t}=\alpha+\beta_{1} R E R_{i t}+\beta_{2} Y_{i t}+\beta_{3} Y_{i t}^{*}+\varepsilon_{i t}
$$

where $(T B / Y)$ is the ratio of the bilateral trade balance between the home country $(\mathrm{H})$ and the foreign country (F) over H's output; RER is the home country's bilateral real exchange rate with $\mathrm{F} ; Y$ and $Y^{*}$ are respectively home and foreign real outputs; and $t, i$, and $\varepsilon_{i t}$ respectively denote time, an index of country pairs (H-F), and a well-behaved error term. ${ }^{5}$ It is generally assumed that increases in foreign (domestic) output provide greater export opportunities to domestic (foreign) firms, i.e., that the trade balance improves (worsens) with $Y^{*}(Y)$. The parameter $\beta_{1}$ bears the primary interest here, as its sign and significance determine the nature of the link between the real exchange rate and the trade balance. As mentioned above, previous studies have found mixed evidence for this relationship.

We modify this model in two respects. First, we replace the real exchange rate in equation (2) with a measure of its misalignment. Such an amendment is motivated by the observation that, in many cases, the lack of movements in real exchange rates can be as important as movements in these real exchange rates for the trade balance. The most obvious illustration of this fact is the case of US-China bilateral trade. Following the devaluation of its currency in January $1^{\text {st }}, 1994$, China entered a period of dollar de facto pegging of the renminbi, which lasted until July 21st, 2005, when the People's Bank of China showed the first signs of its willingness to move towards more flexibility of the renminbi. Figure 1 displays the evolutions of China's bilateral real exchange rate with the US, as well as its real effective exchange rate, during the "fixity period" of the renminbi, together with the China-US bilateral trade balance (excluding oil, ores and metals trade).

\footnotetext{
${ }^{5}$ Admittedly, this model corresponds to a parsimonious view of the trade balance, as the latter is determined by a limited number of variables. We show in section 5 that our main findings survive to the extension of the model to include notably saving and investment-related factors.
} 
Figure 1: US-China bilateral trade

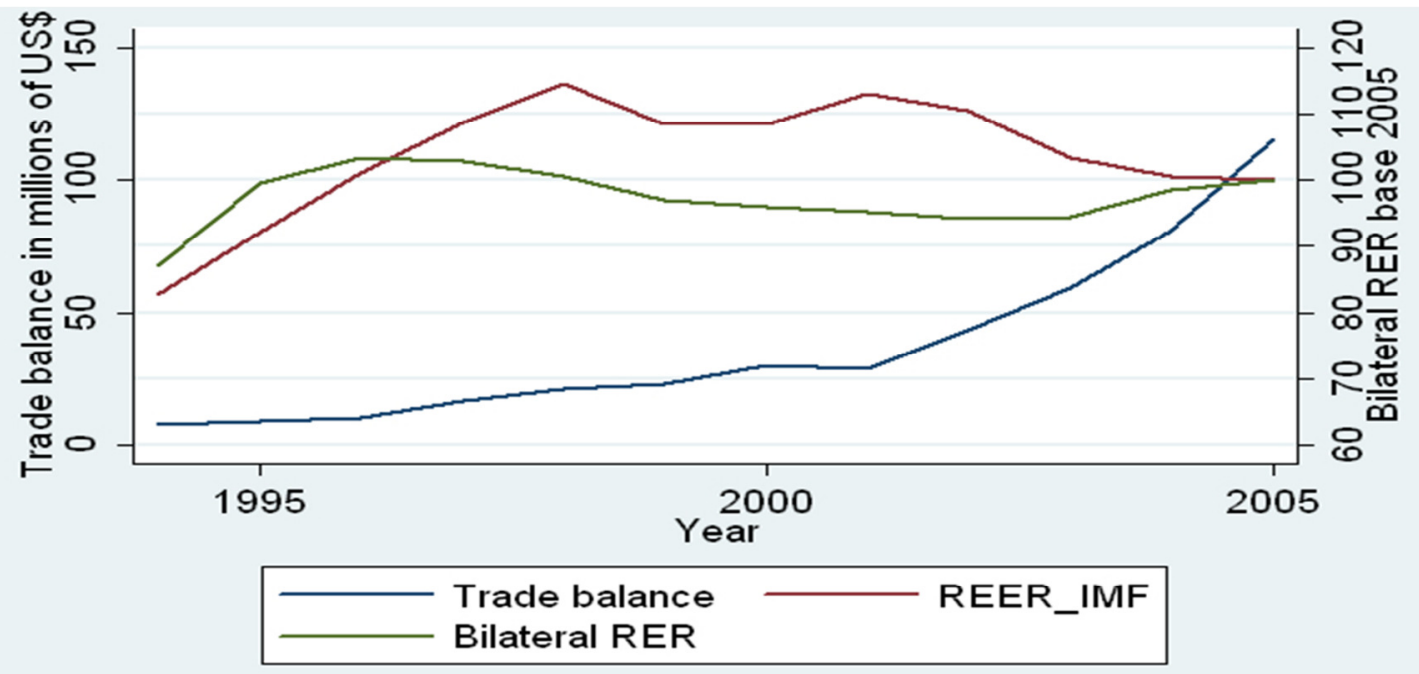

Source: Author's calculations using data from the IFS and Comtrade databases

Figure 2: Ireland-Italy bilateral trade

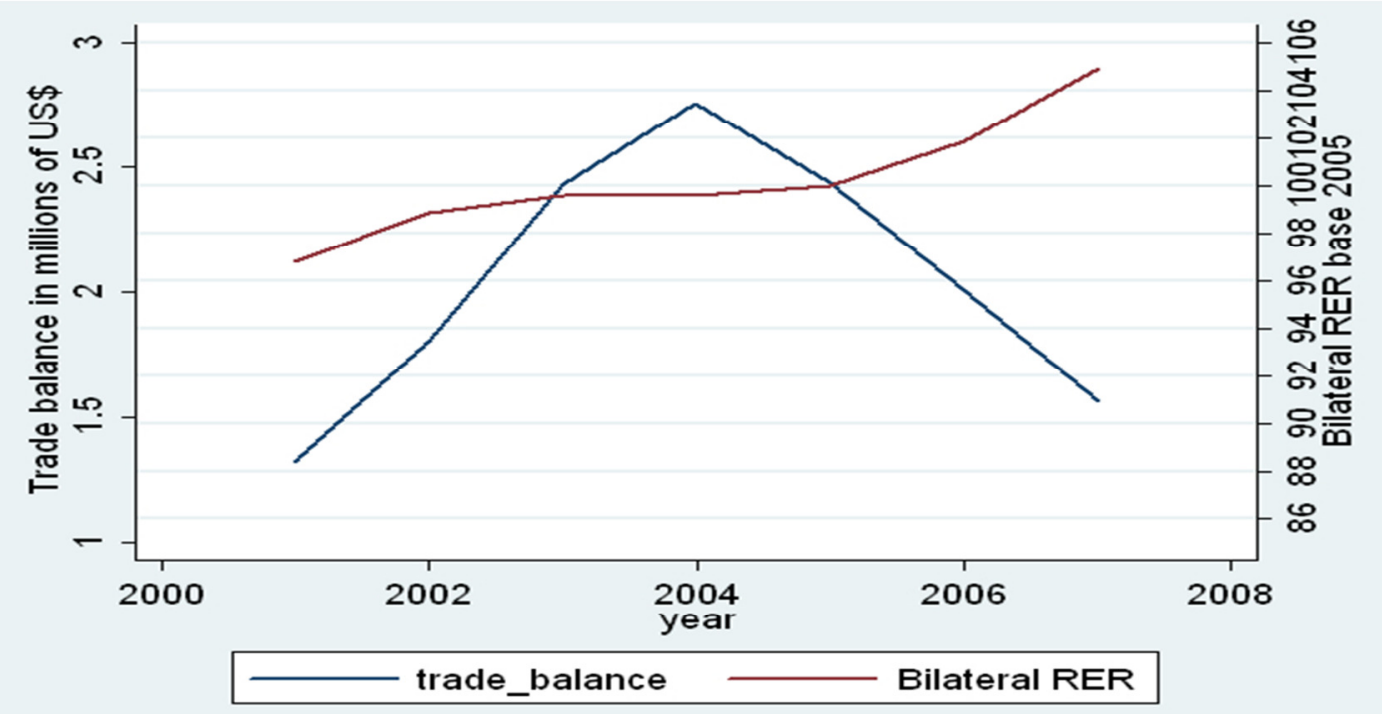

Source: Author's calculations using data from the IFS and Comtrade databases

The bilateral real exchange rate between the two countries has been quite stable over the period. After an initial appreciation due to the high inflation rates that followed the devaluation (over 20\%), the renmninbi displayed a slight depreciation in real terms, before regaining its 1995 real value in 2005 . Regarding the real effective exchange rate (REER_IMF drawn from the IMF's International Financial Statistics (IFS) database), the picture is not so different either. As in the bilateral case, the Chinese real effective exchange rate appreciated following the 1994 devaluation. Afterwards, it underwent several small depreciation and appreciation phases following relative inflation rates in China, before reaching back its 1996 level in 2005. However, most economists would agree that the "equilibrium value" of 
the renminbi, -i.e., the value that would be expected if the currency were to be set so as to reach internal and external balance- has considerably appreciated over this period, at least for two reasons: increasing productivity in the Chinese tradable sector (as per Balassa-Samuelson, see Hsieh and Ossa, 2011 for example) and steady flows of capital mainly in the form of foreign direct investments (see Prasad and Wei, 2005). This situation has led analysts as well as leading scholars to argue that the renminbi was undervalued.

On the other hand, China's bilateral trade balance strongly improved over the period, increasing by over $2000 \%$. Hence, putting together a bilateral real exchange rate globally stable and a bilateral trade balance strongly increasing, estimates using the model above will tend to erroneously conclude that there is no link between the real exchange rate and the trade balance -or underestimate the true effect. Yet, in this case, what matters is the misalignment of the exchange rate. If one believes that the equilibrium value of the renminbi increased over 1994-2005 for the aforementioned reasons, the Chinese currency should have appreciated in real terms over the period. Then, it is the lack of movement in the renminbi's value that has led to an undervaluation of the currency, which in turn could have played a role in the China-US bilateral trade balance improvement.

Even though the most prominent due to the economic size of countries involved, the US-China case is not the only illustration of such misalignments resulting from a lack of adjustment in real exchange rates. Figure 2 displays another less known example of this phenomenon involving two euro-zone countries. It graphs Ireland's bilateral real exchange rate with Italy together with the bilateral trade balance between these two countries (excluding oil, ores and metal products), for the 2001-2007 period. As in the previous example, it is striking how the two series seem to display little connection. On the one hand, the bilateral real exchange rate showed little variation, consecutively going through a $3 \%$ appreciation phase during the period 2001-2003, a stability episode between 2003 and 2005, and a new 4\% appreciation phase from 2005 to 2007. On the other hand, Ireland's trade balance with Italy initially improved by 108\% over the period 2001-2004, before dramatically reversing, as of 2004 . However, such a lack of connection between the exchange rate and the trade balance is only apparent, as suggested by recent estimates of misalignments within the euro zone by Coudert et al. (2012) consistent with our own estimates to be presented below. These authors evidence that Ireland's real exchange rate displayed substantial undervaluation from 2001 to 2004 (more than 15\% in 2002), which corresponds to the improvement phase of Ireland's trade balance with Italy. But most interestingly, they report that Ireland's real exchange rate started to exhibit substantial overvaluation as of 2004, precisely the year of Ireland's bilateral trade balance reversal. Of course, it goes without saying that these figures are based on pure correlations. However, what can be safely said is that; if there were to be causality running from the misalignment of Ireland's real exchange rate to the level of its trade balance with Italy, estimates using the model in equation (2) are not likely to reveal it. Indeed, 
with a bilateral real exchange rate nearly stable and a bilateral trade balance more than doubling before collapsing, it would not be surprising to find a weak statistical link between these two variables.

The two cases discussed above involve very different countries with diverse relationships. But, they carry the same and clear message: misalignments resulting from the lack of (sufficient) variability in real exchange rates can have substantial trade impact, albeit hardly observable when only changes in real exchange rates are considered. ${ }^{6}$

Beyond the fact that it helps us to avoid the problem described above, replacing the real exchange rate in equation (2) with a measure of its misalignment has the advantage of allowing a more explicit estimation of the direct impact of currency misalignment on the trade balance -which is our main goal after all. However, it is reasonable to think that the bilateral trade balance between the domestic and the foreign country is not only determined by the misalignment of the home currency, but by misalignments in both home and foreign currencies. Accordingly, in addition to the misalignment of the domestic currency, we add to the specification in equation (2) the misalignment rate of the foreign currency. Eventually, our empirical specification takes the following form:

$$
\left({ }^{T B} /{ }_{Y}\right)_{i t}=\alpha+\beta_{1} \text { MISALIGN }_{i t}+\beta_{2} \text { MISALIGN }^{*}{ }_{i t}+\beta_{3} Y_{i t}+\beta_{3} Y_{i t}^{*}+f_{H F}+f+f^{*}+f_{t}+\varepsilon_{i t}(3)
$$

where $(T B / Y)$ is the ratio of the bilateral trade balance between $\mathrm{H}$ and $\mathrm{F}$ over $\mathrm{H}$ 's output; MISALIGN $_{i t}$ and MISALIGN ${ }^{*}$ it are measures of the degree of undervaluation (as well as overvaluation) respectively in the domestic and the foreign currency; and $f_{H F}, f, f^{*}, f_{t}$ stand for pair, home country, foreign country, and time fixed effects, respectively. Our primary interest lies on $\beta_{1}$ and $\beta_{2}$; but most importantly on the latter which defines the impact of the foreign currency misalignment on the domestic trade balance. Concretely, for China's case for example, $\beta_{1}$ will capture the effect of the probable undervaluation of the renminbi on China's trade balances with the US, Japan, SouthKorea, Brazil etc. On the other hand, $\beta_{2}$ will cumulate the impacts of the misalignment of the dollar on China's trade balance with the US, the misalignment of the yen on China's trade balance with Japan, the misalignment of the won on China's trade balance with South Korea and so on. Hence, $\beta_{2}$ tells us how do foreign exchange rate policies affect China's trade balance -we call this "the external effect"while $\beta_{1}$ quantifies the impact of China's own exchange rate policy on its trade balance -we call this "the internal effect". But instead of focusing on China we exploit the cross-national experience of all countries in the sample.

\footnotetext{
${ }^{6}$ This feature is particularly frequent in pegged regimes. Indeed, by preventing the nominal exchange rate from adjusting, pegged regimes leave the entire brunt of real exchange rate adjustments to price levels. Even though there is some mechanisms easing such an adjustment in prices (for example, the decrease in the demand for non tradables following a real appreciation could help reduce inflation relative to the ROW, allowing the depreciation of the real exchange rate), these are not necessarily strong enough to bring exchange rates back to their equilibrium levels. In the latter case, real exchange rates tend to be rigid as little room is left for their adjustment (see Coudert and Couharde, 2009 for example).
} 
One important feature of the model is the fact that misalignments are multilateral here (or expressed with respect to a base country). This gives to our specification another noteworthy advantage over the standard model in equation (2): it accounts for third-country effects -i.e., the fact that trade between Germany and France, for instance, does not only depend on the evolution of relative prices in these two countries, but also on what is happening in India for example. A recent illustration of the importance of this third dimension of trade is given by Chen et al., (2012)'s analysis of intra-European imbalances. These authors evidenced that one of the main drivers of trade imbalances within the euro area is to be searched for outside of Europe, more precisely in China's emergence.

Before proceeding further, it is worth mentioning that, in practice, the foreign currency misalignment is not the mirror image of the home currency misalignment, as one might think. Currency misalignment is usually measured as the deviation of the real exchange rate from the level predicted by the value of the country's own fundamentals, using the in-sample average relationship between the real exchange rate and the fundamentals. Therefore, there is no reason to believe that the implied misalignments will be symmetric. In fact, the correlation coefficients between our different measures of home and foreign currency misalignments -to be presented in detail in section 4- are actually positive and range from 0.05 to $0.19 .^{7}$ Moreover, omitting the foreign currency misalignment in equation (3) would imply that undervaluation of the home currency affects the domestic trade balance in the same manner regardless of whether the partner has an undervalued, at equilibrium, or overvalued currency; which seems unlikely. ${ }^{8}$

Finally, we do not aim at estimating the whole complexity of the microeconomic response of firms in home and foreign markets to exchange rate changes. There is a vast microeconomic literature highlighting several critical factors in the chain of "reactions" going from currency undervaluation to an effective expenditure-switching between home and foreign products. For example, Francois (2010) showed that a substantial fraction of US firms could be adversely affected by an appreciation of the renminbi as they heavily rely on inputs produced in China, which become more expensive. Similarly, Eichengreen and Tong (2011) evidenced that foreign firms that provide China's exporters with parts and components could be equally negatively affected by renminbi appreciation, since the latter could induce a shift away of China's industries from assemblage activities. Furthermore, a growing body of

\footnotetext{
${ }^{7}$ For example, in 2007, the average misalignment of Malaysia's partners' currencies pointed to an overall undervaluation, as many of these mostly-Asian countries also exhibited undervaluation in their currencies, even though Malaysia's currency itself was found to be undervalued. The same applies to France's overvaluation as well as China's undervaluation for example (see section 4 for a detailed description of our misalignment measures).

${ }^{8}$ A possible source of concern in this model is the fact that trade balances are bilateral, whereas undervaluation measures are multilateral here. However, if anything, this would lead to an underestimation of $\beta_{1}$ and $\beta_{2}$. To see it, consider the case of a domestic currency undervaluation of $50 \%$ for example. Given the positive correlation between our measures of home and foreign misalignments, such a home currency undervaluation is likely to be concomitant with an undervaluation of the foreign currency, say of $20 \%$. In this case, $\beta_{1}$ will not be capturing the impact of a $50 \%$ undervaluation, as suggested by our multilateral measure, but the effect of the true bilateral misalignment, i.e., an undervaluation rate of somewhere around $30 \%$. Similarly, $\beta_{2}$ will not be estimating the impact of a $20 \%$ undervaluation of the foreign currency but that of the true bilateral misalignment, i.e., an overvaluation. Therefore, in both cases we are underestimating the potential for undervaluationinduced pro-competitive gains. The same logic applies to the case of a home currency overvaluation.
} 
papers, surveyed in Galindo et al. (2003), emphasized the adverse balance sheet effects that can result from a depreciation of the currency, if firms borrow in foreign currency or incurred foreign-currencydenominated sunk costs. Finally, the results from the model above are naturally subject to the "aggregation bias" common to all macroeconomic trade studies, as the trade impact of exchange rate undervaluation can vary across products, firms or sectors. We rather adopt a macroenomic approach here. Then, the implicit question is whether the price incentive provided by currency undervaluation is sufficiently strong to dominate these negative microeconomic effects. Moreover, although getting the best handle possible on these microeconomic phenomena is essential to a good understanding of current trade issues, as Imbs and Mejean (2008) put it: "after all it is the response of aggregate quantities that macroeconomists are interested in" (p. 1).

\section{Data and Estimation strategy}

\subsection{Data}

The analysis is conducted on bilateral trade data for a large panel of 62 countries and their ten most important partners over the period 1990-2007. The basic dataset comprises annual data for 28 developed countries and 34 emerging markets, covering more than $90 \%$ of world trade. Table A1 displays an exhaustive list of countries considered in this study. The choice of the sample has been mainly guided by data availability. We restrained the analysis to the post 1990 period to focus on latest developments in global trade. Trade data as well as consumer price indexes and exchange rate data are respectively drawn from the UN COMTRADE and IFS databases.

The trade balance variable is defined here as the home country's net exports to the foreign country expressed as a ratio of home GDP. ${ }^{9}$ We exclude from this measure the trade in oil, ores and metal products, as the latter usually display low price elasticities and are not likely to be subject to expenditure switching across countries. Domestic and foreign outputs are respectively proxied by the home country and the foreign country's real GDPs, using data from the Penn World Tables version 7.0 (PWT 7). The ten largest partners are determined on the basis of partners' shares in total home exports and imports -excluding trade in oil, ores and metal products- over the period 1996-2006.

\subsection{Measuring undervaluation}

The question of the appropriate measure of currency misalignment is one of the most contentious issues in applied macroeconomics. Several competing procedures are available, each reflecting a particular definition of the "equilibrium exchange rate". The most popular ones are probably misalignment indexes based on the "enhanced purchasing power parity" (PPP) criterion, the so-called fundamental equilibrium exchange rate (FEER, Williamson, 1985) and the behavioral equilibrium exchange rate (BEER, Macdonald, 1997). Conceptually, the enhanced-PPP measure is derived from

\footnotetext{
${ }^{9}$ Note that such a ratio is unit-free as both the trade balance and the GDP are expressed in current US dollar.
} 
the international comparison of price levels across countries (possibly adjusted for the changes in one or more "fundamentals"), while the FEER measure aims at assessing the departure of the exchange rate from the level that would be consistent with a "target current account". ${ }^{10}$ The BEER approach is a cointegration-based view of equilibrium exchange rates, aiming at directly linking the latter equilibrium to some "economic fundamentals". Except for the enhanced-PPP approach, all these measures are expressed in a multilateral basis. Another noticeable conceptual difference between these three schools of approaches relates to the time horizon considered: the very long run for the enhanced PPP measure, the medium run for the FEER approach and in between for the BEER concept (see Bénassy-Quéré et al., 2010).

A constant effort is made throughout this paper not to let the controversies on the appropriate measure of undervaluation "pollute" the assessment of the issue of primary interest here -which is the external consequences of currency undervaluation strategies that might have been adopted by some countries. Each of the three aforementioned approaches has its advantages and drawbacks. The enhanced-PPP approach has the upsides of being simple to compute, involving direct comparisons of real exchange rates in levels (rather than indices as in the BEER procedure, which matters for the cross-country comparability of estimated equilibrium RERs), and yielding general equilibrium estimates by nature (see Subramanian, 2010). It has however the drawbacks of considering a narrower definition of macroeconomic equilibrium compared to the two other procedures, and deducing misalignment measures with respect to a base country (the U.S.A. here), which is not always the pertinent standard for assessing pressures from foreign competition. On the other hand, the BEER approach is consistent with a broader concept of macroeconomic equilibrium but has the drawback of assuming implicitly that the currency was in equilibrium, on average, over the study period. Finally, the FEER approach has the advantage of linking more explicitly the estimated misalignment to the need of current account sustainability but relies heavily on the chosen values of target current accounts and current account semi-elasticities.

In light of these considerations, it is clear that exchange rate assessments by means of one approach need to be systematically completed with robustness tests using an alternative measure. In this paper, we report evidence exploiting various misalignment indexes based on the two most routinely used misalignment measurement approaches in the literature: enhanced-PPP and BEER. In what follows, we present the main features of these indexes.

\footnotetext{
${ }^{10}$ In fact as in the other procedures, the equilibrium exchange rate derived from the FEER approach is also consistent with internal balance, but this side of the equilibrium is less the object of debate; much of the controversy is related to the appropriate definition of external balance.
} 


\subsubsection{Enhanced-PPP misalignment indexes}

Building on a long-standing tradition in economics (Froot and Rogoff, 1996 and Rodrik, 2008 inter alia), the enhanced-PPP misalignment indexes used in this paper are based on the standard PPP criterion, adjusted for the changes in some "fundamentals". Their computation follows three steps.

We first calculate the "real" exchange rate in level $\left(R E R_{i t}\right)$ or relative price level of GDP as follows using data from the PWT $7:^{11}$

$$
\log \left(R E R_{i t}\right)=\log \left(X R A T_{i t} / P P P_{i t}\right)=\log \left(P_{u s a} / P_{i}\right)
$$

where $X R A T_{i t}$ is the nominal exchange rate of the domestic currency against the U.S. dollar, $P P P_{i t}$ is the PPP exchange rate, $P_{u s a}$ is the price level in the U.S.A., $P_{i}$ is the price level in country $i$ and $t$ indexes time. This first step gives the simplest version of the PPP-based misalignment index. As absolute respect of PPP implies that $R E R_{i t}$ equals one, a positive value of $\log \left(R E R_{i t}\right)$ reveals an undervaluation and a negative value entails an overvaluation of $R E R_{i t}$. However, it is now well-known that exchange rates can persistently diverge from PPP as a result of permanent changes in "fundamentals". Hence, an adjustment is required for such entirely market-driven developments, giving the "enhanced" PPP misalignment measure.

Several aspects are critical in the choice of the appropriate vector of fundamentals. First, the latter must be chosen so as to account for both internal and external balances. Second, some fundamentals, such as the tradable-non-tradable sectors productivity gap (the Balassa-Samuelson effect) and to a lesser extent, net foreign assets, are known to be the primary long-term determinants of the equilibrium exchange rate; so, these are in pole position among candidates. Third, contingent to the degree of sample heterogeneity, the equilibrium RER can be well characterized by means of a more or less long list of fundamentals. When a relatively homogeneous group of countries is considered, a limited vector of fundamentals, including only the Balassa-Samuelson effect and net foreign assets, can do the trick. But when the study sample is relatively heterogeneous, such a strategy would yield excessive misalignment estimates. Thus, a longer list of fundamentals needs to be considered to efficiently characterize the equilibrium RER.

To date, most of the literature retains as the unique fundamental the real GDP per capita (aiming at estimating the Balassa-Samuelson effect). Nevertheless, we are generally skeptical of these measures since they have the drawback of only accounting for internal balance considerations. An implicit assumption here is that external balance is met, that is, relative prices have adjust so as to correct any persistent disequilibrium in the external account (Eichengreen, 2007); which is quite strong a postulate given the current state of external accounts around the world.

\footnotetext{
${ }^{11}$ The second version of China's data, labeled "China2" in the PWT 7 — which adjusts for the urban character of Chinese prices in ICP 2005- are used.
} 
As a remedy, we therefore compute two enhanced-PPP misalignment indexes: a first index adjusting only for the Balassa-Samuelson effect, in line with what is generally done in the literature; and a second measure accounting also for the external balance conditions by adding net foreign assets to the list of fundamentals. This is done by estimating the following equations:

$$
\begin{gathered}
\log \left(R E R_{i t}^{1}\right)=\alpha+\beta \log \left(R G D P C H_{i t}\right)+f_{t}+\varepsilon_{i t}(5) \\
\log \left(R E R_{i t}^{2}\right)=\gamma+\delta \log \left(R G D P C H_{i t}\right)+\theta n f a_{i t}+f_{t}+\varepsilon_{i t}
\end{gathered}
$$

where $R G D P C H_{i t}$ is the real GDP per capita from the PWT 7, $n f a_{i t}$ is country $i$ 's net foreign assets to GDP ratio minus the US net foreign assets to GDP taken from Lane and Milesi-Ferretti (2007), and $\left(f_{t}\right)$ is a full set of time fixed effects. The coefficients $\beta$ and $\delta$ tell us on average how much a country's real exchange rate tends to appreciate as it becomes richer (as predicted by Balassa-Samuelson); while $\theta$ tells us which part of the countries' RER appreciations can be fully imputable to positive developments in their external accounts. Then, the fitted values from these two equations capture the part of changes in RER that can be seen as "natural", i.e., the fraction that does not reflect any misalignment of the currency.

In order to ward off any non-stationarity or endogeneity problems, we rely on the pooled mean group approach (PMG, Pesaran et al., 1999) to estimate equations (5) and (6). Indeed, as evidenced by the results of stationarity and cointegration tests reported in columns 1.1 and 1.2 of Appendix Table A2, the series seem to exhibit unit roots and do not diverge in the long run. We also extended the study period to 1970-2007, as enhanced-PPP requires a long-term perspective. Appendix Table A3 displays the estimated vector of fundamentals for each of our equilibrium RER equations.

Finally, the enhanced-PPP misalignment indexes, misppp $p_{i t}^{1}$ and $m i s p p p_{i t}^{2}$, are obtained by deducting from the current PPP-value of $R E R_{i t}$, the fraction that is entirely driven by changes in fundamentals, i.e., the fitted values from equation (5) and (6), respectively $\widehat{R E R_{l t}^{1}}$ and $\widehat{R E R_{l t}^{2}}$ :

$$
\begin{aligned}
& \operatorname{misppp}_{i t}^{1}=\log \left(R E R_{i t}\right)-\log \left(\widehat{R E R_{l t}^{1}}\right) \\
& \text { misppp }_{i t}^{2}=\log \left(R E R_{i t}\right)-\log \left(\widehat{R E R_{l t}^{2}}\right)
\end{aligned}
$$

A positive value of these indexes indicates that the exchange rate is set such that the price level at home is lower than predicted by purchasing power parity: the real exchange rate is undervalued. Conversely, a negative value of mispppit or misppp $p_{i t}^{2}$ implies that the real exchange rate is overvalued.

\subsubsection{Behavioral equilibrium exchange rate-based misalignment indexes}

In this section, we present the computation of our alternative misalignment indexes based on the BEER approach. The strategy here is to identify a structural long-term relationship between the real effective exchange rate (REER) and some economic fundamentals. The equilibrium REER is then 
predicted from this equation and confronted to the market REER to determine its misalignment. As in the enhanced-PPP approach, the crux of the methodology is the choice of the fundamentals. But unlike enhanced-PPP, BEER is a multilateral approach: real effective exchange rate indices are used instead of bilateral real exchange rates in levels.

As previously, we also compute here two indexes of exchange rate misalignment. The first measure uses as sole fundamentals a productivity gap variable $\left(\right.$ balass $\left._{i t}\right)$-aiming at capturing BalassaSamuelson effects- and net foreign assets to GDP $\left(n f a_{i t}\right)$. In the second index, we adopt a larger vector of fundamentals, by adding to the precedent list the commodity terms of trade $\left(\operatorname{tot}_{i t}\right)$, the degree of trade openness $\left(\right.$ trade $\left._{i t}\right)$ and public expenditures $\left(g_{i t}\right)$. The following long run REER equations are then estimated:

$$
\begin{gathered}
\text { reer }_{i t}=a+b_{1} \text { balassa }_{i t}+b_{2} n f a_{i t}+\varepsilon_{i t} \\
\text { (9) } \\
\text { reer }_{i t}=\alpha+\beta_{1} \text { tot }_{i t}+\beta_{2} n f a_{i t}+\beta_{3} \text { trade }_{i t}+\beta_{4} g_{i t}+\beta_{5} \text { balassa }_{i t}+u_{i t}
\end{gathered}
$$

where reer $_{i t}$ is the CPI based real effective exchange rate. The weights used for its calculation are computed as the share of each partner in average values of imports and exports of goods and services over the 2000-2007 period. An increase in this variable implies a real appreciation. The BalassaSamuelson effect is proxied by the ratio of the domestic country's GDP relative to the weighted GDP of trade partners, using the same weighting matrix as for the reer $_{i t}$ (Aguirre and Calderon, 2005). The remaining variables are taken from the World Development Indicators (WDI) and IFS databases. All series are in logarithm except for $n f a_{i t}$.

The real effective exchange rate is expected to appreciate with (i) positive developments in terms of trade, leading to an improvement in the trade balance, (ii) an increase in trade restrictions, resulting in higher domestic prices (iii), a faster tradables to non-tradables relative productivity growth at home than abroad, in line with the Balassa-Samuelson effect, (iv) an increase in the country's net foreign assets position, due to the implied "transfer effect", and (v) an expansion of the government's size because of the well-known "home bias" in public expenditures. In other words all parameters in equations (9) and (10) are expected to be positive, except for that on trade.

To estimate these long-run REER equations, we rely on panel cointegration techniques. As in the previous section, we start by assessing the validity of these equations as long run relationships, by checking both the non-stationarity of series and the existence of a cointegration relationship between the REER and its economic fundamentals. Results, reported in columns 1.3 and 1.4 of Appendix Table A2, confirm these preconditions allowing the estimation of equations (9) and (10). By the same token as previously, the PMG estimator is applied to these equations, yielding the results displayed in Appendix Table A4. For each of these equations, the fitted value defines the equilibrium real effective exchange rate, i.e., the REER that should prevail given the level of fundamentals. 
Finally, the BEER-based misalignment indexes (misbeer ${ }_{i t}^{1}$ and misbeer $_{i t}^{2}$ ) are measured as the deviation of the REER from its equilibrium level $\left(E R E E R^{k}{ }_{i t}\right)$ :

$$
\text { misbeer }_{i t}^{k}=E R E E R_{i t}^{k}-\operatorname{REER}_{i t}(7) \text { and } \quad E R E E R^{k}{ }_{i t}=\widehat{\beta^{k}} X_{H P}^{k} \quad k \in\{1,2\}
$$

where $\widehat{\beta^{k}}$ stands for the estimated matrix of parameters in equations (9) and (10), and $X_{H P}^{k}$ is the (Hodrick-Prescott) filtered long term value of fundamentals. Thus defined, a positive value of misbeer ${ }_{i t}$ reveals an undervaluation and a negative value of this variable is associated with an overvaluation of the currency.

Overall, we compute four misalignment measures: two indexes based on enhanced-PPP and two others derived from the BEER approach. Unsurprisingly, the correlation is larger between indexes based on the same approach of exchange rate assessment (around 85\%) than indexes derived from different approaches (34\% to 42\%), as witnessed in Appendix Table A5. Such discrepancies across approaches are further confirmed when we look at our detailed misalignment estimates for China, the US, Japan, Germany, India and Brazil in 2007 reported in Table 1.

For the US case, estimates are globally consistent across approaches and point to an overvaluation of $0.8 \%$ to $3 \%$. On the other hand, estimates for Japan and Germany's cases display a little more dispersion, going from a $7 \%$ undervaluation to a $4 \%$ overvaluation, and a $3 \%$ undervaluation to a $6 \%$ overvaluation respectively. The larger differences across estimates are observed for China, India and Brazil. Although diagnostics on the direction of the misalignment are similar across indexes, divergences in the estimated magnitude can be sizable: a $19 \%$ to $48 \%$ undervaluation for the Chinese renminbi, a $14 \%$ to $34 \%$ undervaluation for the Indian rupee and a $15 \%$ to $30 \%$ overvaluation for the Brazilian real.

Table1: Misalignment estimates for selected countries in 2007

\begin{tabular}{lrccccc}
\hline & \multicolumn{1}{l}{ China } & Japan & USA & Germany & India & Brazil \\
Misppp $^{1}$ & $45 \%$ & $-3 \%$ & $-2 \%$ & $-4 \%$ & $31 \%$ & $-15 \%$ \\
Misppp $^{2}$ & $48 \%$ & $-4 \%$ & $-2 \%$ & $-6 \%$ & $34 \%$ & $-20 \%$ \\
Misbeer $^{1}$ & $19 \%$ & $7 \%$ & $-3 \%$ & $3 \%$ & $14 \%$ & $-23 \%$ \\
Misbeer $^{2}$ & $25 \%$ & $-0.3 \%$ & $-0.8 \%$ & $-3 \%$ & $19 \%$ & $-30 \%$ \\
\hline
\end{tabular}

Note: a positive (negative) value reveals an undervaluation (overvaluation). Misppp ${ }^{1}$ and misppp ${ }^{2}$ are enhanced-PPP indexes respectively adjusted for the Balassa-Samuelson effect and both the Balassa-Samuelson effect and net foreign assets. Misbeer ${ }^{1}$ is a BEER-based index using as fundamentals a proxy for the Balassa-Samuelson effect and net foreign assets. Misppp ${ }^{2}$ add to the latter list terms of trade, public expenditures and trade openness.

Note that a positive correlation between the trade balance and our misalignment measures is consistent with both an export-promoting effect of undervaluation and a detrimental effect of overvaluation. Below, we focus on the undervaluation side in the interpretation of results since our economic interest 
relies on this side of the misalignment. We also present evidence further identifying the impact of undervaluation with respect to overvaluation.

\subsection{Estimation strategy}

Two crucial problems one must solve before estimating the model are the potential non stationarity of some of the variables in the model as well as the endogeneity of home and foreign misalignments. Permanent changes in the trade balance are likely to affect the equilibrium real exchange rate and therefore, the misalignment of the currency, resulting in a reverse causality between currency misalignment and the trade balance. The first best strategy to simultaneously address these two problems would be to estimate the model by means of panel cointegration techniques, which are immune from both issues. However, two preconditions for these techniques to be valid are the existence of unit roots in each of the variables in the model, as well as a cointegration relationship between the latter. The results of second generation panel unit root tests, displayed in column 1.5 of Appendix Table A2, suggest that only the home and foreign country real GDPs seem to exhibit unit roots, ruling out the possibility to rely on panel cointegration techniques to estimate the model.

As a result, we first introduce the latter variables in first-differenced form to address the issue of their non stationarity. ${ }^{12}$ The same unit root tests as previously, applied to these differenced variables, confirm that they are stationary (see column 1.5 of Appendix Table A2). Second, we base our main conclusions on estimates using dynamic panel GMM estimators (Arellano and Bond, 1991 and Blundell and Bond, 1998) to remedy the endogeneity issue. ${ }^{13}$ These estimators provide an efficient identification strategy by exploiting an internal instrumentation structure (see Roodman, 2006 for a comprehensive user's guide). Furthermore, GMM estimators are particularly suitable here, as (i) our dataset is characterized by a small number of time periods $T$ with respect to the number of groups $N$ ( $\mathrm{N}=620$ and $\mathrm{T}=18$ ), a framework in which GMM estimators are highly recommended (Pedroni, 1999), (ii) a widely admitted feature of trade flows is the hysteresis that characterizes them, suggesting that the appropriate trade balance model would be a dynamic one. We rely more particularly upon the Blundell and Bond (1998)'s system GMM estimator as it provides the most efficient identification strategy. As suggested by conventional econometric practice, we systematically check that: (i) both pvalues associated with the Sargan and Hansen statistics do not reject the over-identifying restrictions confirming the validity of instruments; (ii) the $\mathrm{AR}(1)$ test statistics rejects the null of no first-order autocorrelation in error terms, while the Arellano-Bond test for $\operatorname{AR}(2)$ fails to reject the null of no second-order autocorrelation in residuals, (iii) the instruments count is sufficiently low to avoid problems related to the "over-fitting bias" (see Roodman, 2008).

\footnotetext{
${ }^{12}$ Results -available from the author- are similar when we keep the home and foreign real GDP variables in level.

${ }^{13}$ Note that all pair and country specific fixed factors are dropped out with the GMM framework.
} 


\section{Results}

We start by reporting the estimation of our baseline model in columns 2.1-2.8 of Table 2, using the cross-national experience of all countries in the dataset, as well as the system GMM and difference GMM estimators that help us to identify a truly causal effect. We replicate the estimation for all four misalignment indexes to ensure that the results are independent to the measure of undervaluation. Columns 2.1-2.4 report estimates using the difference GMM estimator, and the last five columns display the results when the system GMM estimator is applied to our basic model. All regressions are clustered at the pair country level.

Table 2: Baseline results

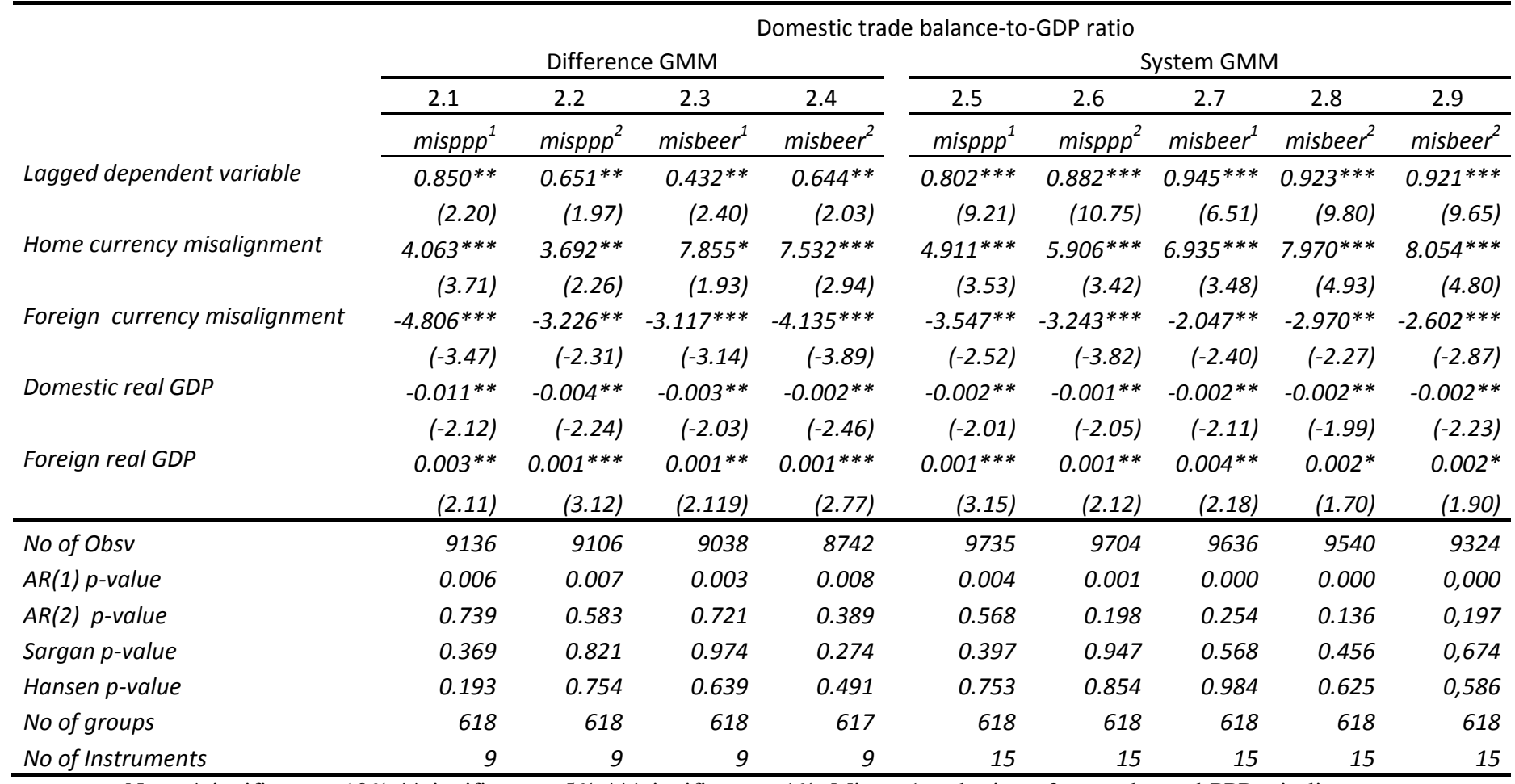

Note: *significant at $10 \% * *$ significant at $5 \% * * *$ significant at $1 \%$. Misppp1 and misppp2 are enhanced-PPP misalignment indexes respectively adjusted for the Balassa-Samuelson effect and both the Balassa-Samuelson effect and net foreign assets. Misbeer1 is a BEER-based misalignment index using as fundamentals a proxy for the Balassa-Samuelson effect and net foreign assets. Misppp2 add to the latter list terms of trade, public expenditures and trade openness. The home and foreign GDP variables are introduced in first-differenced form

The results are quite stable across estimators and undervaluation measures. They give strong support to the beggar-thy-neighbor hypothesis. We find that undervaluation of the home currency is robustly and significantly associated with an improvement in the domestic trade balance. The estimated effect is highly significant and suggests, on average, a 0.4 to 0.8 percentage points improvement in bilateral trade balances with partners for each $10 \%$ increase in the undervaluation of the home currency. Noticeably, such a result stands out from previous attempts in the literature by its robustness: the estimated effect is significant at the $1 \%$ standard in most of the regressions. This gives additional credit to our empirical specification compared to the poor performance of the standard model in equation (2). 
A second interesting finding one can gather from these estimates is that countries that keep their currencies undervalued tend to negatively impact the other countries' trade balances, as evidenced by the negative sign on the foreign-currency-undervaluation variable. A $10 \%$ increase in the average undervaluation of foreign countries' currencies decreases the home bilateral trade balances with these countries by 0.2 to 0.5 percentage points on average. Such a magnitude implies that a $35 \%$ undervaluation in the foreign country's currency, i.e., our mean estimate for China in 2007, reduces the home trade balance with this country by 0.7 to 1.75 percentage points on average. Interestingly, these effects turn out to be particularly robust: they survive to the exclusion of high misalignment observations (undervaluation and overvaluation rates over 50\%), as in column 2.9, suggesting that the expenditure-switching effect of exchange rates operates even in the case of relatively moderate misalignments. As expected, the home and foreign real GDP variables respectively bear positive and negative signs.

Turning to the sizes of our internal and external effects, they could differ in the plausible case of asymmetries in home and foreign currencies' pass-throughs. Indeed, if there is one thing we can learn from the bourgeoning literature on exchange rate pass-through, it is that both export and import passthroughs tend to be higher during depreciations than during appreciations (see Bussière, 2007 and Delatte and López-Villavicencio, 2012 for example). Therefore, depending on the structure of asymmetries in home and foreign currencies' pass-throughs, undervaluation of the foreign currency could worsen the trade balance more that the home undervaluation improves it, or vice versa. In fact, this latter case seems to dominate in most of our estimates as suggested by formal tests for equality of size between our internal and external effects.

In what follows, we submit these baseline results to a series of robustness checks. For brevity, we only report here estimates based on the first version of our enhanced-PPP undervaluation index (adjusted only for the Balassa-Samuelson effect) and the second version of our BEER-based undervaluation measure (using a large vector of fundamentals). Similarly, only estimates using the system GMM estimator are reported. The results are qualitatively similar when the other undervaluation indexes as well as the difference GMM estimator are used. ${ }^{14}$

In columns 3.1 and 3.2 of Table 3, we further identify the trade impact of currency undervaluation by breaking up each of the home and foreign misalignment indexes into their undervaluation and overvaluation components. As mentioned above, the misalignment indexes contain observations of both sides of the misalignment, meaning that a positive correlation between these indexes and the trade balance is consistent with an export-enhancing effect of undervaluation as well as a harmful impact of overvaluation. Therefore, our results could be only reflecting a strong adverse effect of overvaluation outweighing a non-significant effect of undervaluation. As a result, we define the

\footnotetext{
${ }^{14}$ They are available upon request to the author.
} 
dummy $D_{t}^{k}$ which takes the value of 1 when the real exchange rate is undervalued and 0 otherwise. Then, we compute our enhanced-PPP undervaluation and overvaluation variables respectively as underppp $_{i t}^{k}=\operatorname{misppp}_{i t}^{k} \cdot D_{t}^{k}$ and $\operatorname{overppp}_{i t}^{k}=\operatorname{misppp}_{i t}^{k} \cdot\left(1-D_{t}^{k}\right)$. The BEER-based misalignment indexes have been similarly broken up, providing us with BEER-based undervaluation and overvaluation indexes: underbeer ${ }_{i t}^{k}$ and overbeer $r_{i t}^{k}$, respectively. These variables are next introduced in our basic specification in equation (3), instead of the composite misalignment variables. The model contains now four misalignment variables: undervaluation and overvaluation of the home currency, as well as the same variables for the foreign country. We recode overvaluation figures to be positive for simplicity of the interpretation.

Table3 Robustness checks

\begin{tabular}{|c|c|c|c|c|c|c|c|c|}
\hline & \multicolumn{8}{|c|}{ Domestic trade balance-to-GDP ratio } \\
\hline & 3.1 & 3.2 & 3.3 & 3.4 & 3.5 & 3.6 & 3.7 & 3.8 \\
\hline & misppp $^{1}$ & misbeer $^{2}$ & misppp $^{1}$ & misbeer $^{2}$ & misppp $^{1}$ & misbeer $^{2}$ & misppp $^{1}$ & misbeer $^{2}$ \\
\hline Lagged dependent variable & $\begin{array}{r}0.786 * * * \\
(8.98)\end{array}$ & $\begin{array}{r}0.913^{* * *} \\
(10.51)\end{array}$ & $\begin{array}{r}0.881 * * * \\
(11.01)\end{array}$ & $\begin{array}{r}0.709 * * * \\
(13.57)\end{array}$ & $\begin{array}{r}0.990 * * * \\
(17.08)\end{array}$ & $\begin{array}{r}0.810^{* * *} \\
(12.31)\end{array}$ & $\begin{array}{r}0.991 * * * \\
(23.51)\end{array}$ & $\begin{array}{r}0.971^{* * *} \\
(18.21)\end{array}$ \\
\hline Home currency undervaluation & $\begin{array}{r}4.865^{* * *} \\
(3.13)\end{array}$ & $\begin{array}{r}8.261^{* * *} \\
(3.54)\end{array}$ & & & & & & \\
\hline Home currency overvaluation & $\begin{array}{r}-5.017 * * * \\
(-2.81)\end{array}$ & $\begin{array}{r}-7.818^{* * *} \\
(-4.87)\end{array}$ & & & & & & \\
\hline Foreign currency undervaluation & $\begin{array}{r}-3.721^{* * *} \\
(-3.68)\end{array}$ & $\begin{array}{r}-2.978^{* *} \\
(-2.04)\end{array}$ & & & & & & \\
\hline Foreign currency overvaluation & $\begin{array}{r}3.213^{*} \\
(1.81)\end{array}$ & $\begin{array}{r}2.643^{* *} \\
(2.49)\end{array}$ & & & & & & \\
\hline Home currency misalignment & & & $\begin{array}{r}5.812^{* * *} \\
(3.45)\end{array}$ & $\begin{array}{r}6.347^{* * *} \\
(3.48)\end{array}$ & $\begin{array}{r}7.760 * * * \\
(3.87)\end{array}$ & $\begin{array}{r}6.668^{* * *} \\
(4.57)\end{array}$ & $\begin{array}{r}6.238^{* * *} \\
(2.88)\end{array}$ & $\begin{array}{r}6.328^{* * *} \\
(4.30)\end{array}$ \\
\hline Foreign currency misalignment & & & $\begin{array}{r}-4.829 * * \\
(-2.49)\end{array}$ & $\begin{array}{r}-5.258^{* * *} \\
(-3.47)\end{array}$ & $\begin{array}{r}-5.666^{* * *} \\
(-3.58)\end{array}$ & $\begin{array}{r}-5.800 * * * \\
(-3.19)\end{array}$ & $\begin{array}{r}-4.370^{* *} \\
(-2.39)\end{array}$ & $\begin{array}{r}-6.221 * * * \\
(-3.49)\end{array}$ \\
\hline Financial depth & & & $\begin{array}{r}2.021 * * * \\
(3.70)\end{array}$ & $\begin{array}{r}1.757^{*} \\
(1.73)\end{array}$ & & & & \\
\hline Dependency ratio (old) & & & $\begin{array}{r}-3.124 * * \\
(-2.24)\end{array}$ & $\begin{array}{r}-3.589 * * \\
(-2.29)\end{array}$ & & & & \\
\hline Government budget balance & & & $\begin{array}{r}0.069^{* *} \\
(2.30)\end{array}$ & $\begin{array}{r}0.050^{* * *} \\
(3.84)\end{array}$ & & & & \\
\hline Terms of trade volatility & & & $\begin{array}{r}-0.001 * \\
(-1.79)\end{array}$ & $\begin{array}{r}-0.002 * * \\
(-2.06)\end{array}$ & & & & \\
\hline Domestic real GDP & $\begin{array}{r}-0.002^{*} \\
(-1.88)\end{array}$ & $\begin{array}{r}-0.001 * * \\
(-2.20)\end{array}$ & $\begin{array}{r}-0.002 * * \\
(-2.11)\end{array}$ & $\begin{array}{r}-0.003 * * * \\
(-2.64)\end{array}$ & $\begin{array}{r}-0.003^{* * *} \\
(-3.78)\end{array}$ & $\begin{array}{r}-0.002 * * \\
(-2.08)\end{array}$ & $\begin{array}{r}-0.002 * * \\
(-2.41)\end{array}$ & $\begin{array}{r}-0.002 * * \\
(-2.25)\end{array}$ \\
\hline Foreign real GDP & $\begin{array}{r}0.001 * \\
(1.79) \\
\end{array}$ & $\begin{array}{r}0.001 * * \\
(2.12)\end{array}$ & $\begin{array}{r}0.003 * * \\
(2.50)\end{array}$ & $\begin{array}{r}0.003 * * * \\
(3.05) \\
\end{array}$ & $\begin{array}{r}0.001^{* * *} \\
(3.60) \\
\end{array}$ & $\begin{array}{r}0.001 * \\
(1.79)\end{array}$ & $\begin{array}{r}0.001^{*} \\
(1.93)\end{array}$ & $\begin{array}{r}0.001 * \\
(1.87) \\
\end{array}$ \\
\hline No of Obsv & 9,735 & 9540 & 6911 & 6805 & 8186 & 7806 & 8228 & 7864 \\
\hline AR(1) p-value & 0.000 & 0.000 & 0.000 & 0.000 & 0.004 & 0.001 & 0.002 & 0.000 \\
\hline$A R(2) p$-value & 0.831 & 0.379 & 0.280 & 0.154 & 0.459 & 0.404 & 0.805 & 0.905 \\
\hline Sargan p-value & 0.639 & 0.654 & 0.754 & 0.396 & 0.432 & 0.450 & 0.287 & 0.184 \\
\hline Hansen $p$-value & 0.158 & 0.629 & 0.369 & 0.817 & 0.743 & 0.287 & 0.563 & 0.556 \\
\hline No of groups & 618 & 618 & 538 & 538 & 527 & 527 & 527 & 527 \\
\hline No of Instruments & 17 & 17 & 22 & 22 & 15 & 15 & 15 & 15 \\
\hline
\end{tabular}


The results globally echo our previous findings. Just as undervaluation of foreign currencies tends to curb domestic exports, overvaluation of partners' currencies is associated with greater export opportunities for home exporters, leading to an improvement of the trade balance. Conversely, undervaluation (overvaluation) of the home currency is associated with positive (negative) developments in the home bilateral trade balance-to-GDP ratios. Most interestingly, for both the home and foreign cases, undervaluation appears to improve the trade balance in a roughly similar degree that overvaluation worsens it.

Columns 3.3 and 3.4 address one of the main criticisms of the expenditure-switching effect of exchange rates, namely the one endorsed by authors such as Mckinnon (2010) who casts doubts on the beggar-thy-neighbor story on the grounds that it tells us nothing on how exchange rate changes could affect the surplus of domestic savings with respect to investment, which equally defines the trade balance. The argument is pertinent, in the sense that more research is clearly needed to reconcile the export-import approach of trade balance analysis with its saving-investment counterpart. But the exact same criticism could be made of trade balance theories that focus on saving and investment behaviors without systematically including exports and imports considerations into the analysis. For example, theories that emphasize the influence of demographics on the trade balance should tell us how population ageing could decrease exports or increase them less than imports. Furthermore, some recent papers suggest the existence of links between the real exchange rate and savings (Balla, 2009; Feenstra, 1998), though there is no consensus yet (Montiel and Servèn, 2008).

To shed light on this issue, we add to our baseline specification robust determinants of the trade balance in the saving-investment approach, such as financial development, the age dependency ratio, the government budget balance and terms of trade volatility in columns 3.3 and 3.4 of Table 3, (see Chinn and Prasad, 2003 for example). Financial development is measured as the stock of claims on the private sector by deposit money banks and other financial institutions, expressed as a ratio of GDP, using data from Beck et al. (2000). We follow Combes and Guillaumont (2002) in estimating terms of trade volatility as the square of residuals of a terms-of-trade equation featuring a mixed trend (both deterministic and stochastic) of the following form: $\log (\text { ToT })_{t}=\alpha+\beta \log (T o T)_{t-1}+\gamma t+\varepsilon_{t}$. Data on government budget balances and age dependency ratios (ratio of older dependents to the workingage population) are drawn from the World Economic Outlook and WDI databases respectively. All these variables are expressed in ratios with respect to the foreign country, except for the government budget balance for which the difference between home and foreign values were computed. Here also, our core results remain globally unaltered by this extension of the model. Moreover, the additional covariates are all significant and display the expected sign (see Chinn and Prasad, 2003 for a detailed discussion on the theoretical foundations of each of these variables).

In our baseline dataset, some pairs of countries mutually appear among each other's top trade partners; meaning that the impact of the misalignment of their currencies will appear in both $\hat{\beta}_{1}$ and $\hat{\beta}_{2}$ (the 
estimated internal and external impacts of currency undervaluation). This is not troublesome per se, as we aim at simultaneously estimating the domestic and foreign trade impacts of these currencies. It should be even less a source of worry given the number of pairs concerned: 182 (i.e. $2 * 91$ ) out of 620 pairs. However, to ensure that our findings are not affected by the presence of these symmetric pairs in the sample, for each pair of countries concerned, we arbitrarily drop the observations of one of the countries and re-estimate the model in columns 3.5 and 3.6. We also replicate the estimations in columns 3.7 and 3.8, dropping, this time, the observations of the other country that was not dropped previously, to ensure that the results are not impacted by our arbitrary decisions. Anecdotally, in columns 3.5 and 3.6, we excluded from the sample the US-China trade observations for which China were the "home country"; hence, the impact of the renminbi's undervaluation on the US-China trade balance appears only in $\hat{\beta}_{2}$ (the external effect of undervaluation). Conversely, in columns 3.7 and 3.8, the impact of China's currency undervaluation on its bilateral trade balance with the US is embedded only in $\hat{\beta}_{1}$ (the internal effect of undervaluation), as US-China trade data for which China appeared as the "foreign country" has been dropped this time. In both cases, our core findings remain unchanged.

Table 4: Further robustness checks

\begin{tabular}{|c|c|c|c|c|c|c|c|c|}
\hline & \multicolumn{8}{|c|}{ Domestic trade balance-to-GDP ratio } \\
\hline & 4.1 & 4.2 & 4.3 & 4.4 & 4.5 & 4.6 & 4.7 & 4.8 \\
\hline & misppp $^{1}$ & misbeer $^{2}$ & misppp $^{1}$ & misbeer $^{2}$ & misppp $^{1}$ & misbeer $^{2}$ & misppp $^{1}$ & misbeer $^{2}$ \\
\hline \multirow[t]{2}{*}{ Lagged dependent variable } & $0.888 * * *$ & $0.873^{* * *}$ & $0.949 * * *$ & $0.807^{* * *}$ & $0.942 * * *$ & $0.969 * * *$ & $0.825 * * *$ & $0.849 * * *$ \\
\hline & (10.23) & (11.36) & (8.82) & (10.01) & (19.93) & (8.44) & (9.69) & (8.68) \\
\hline \multirow[t]{2}{*}{ Home currency misalignment. } & $3.793^{* *}$ & $3.282 * * *$ & $11.056^{* *}$ & $4.927^{* *}$ & & & $4.652 * * *$ & $7.448 * * *$ \\
\hline & (2.06) & (3.64) & (2.47) & (2.19) & & & (3.00) & (3.14) \\
\hline \multirow[t]{2}{*}{ Foreign currency misalignment } & $-6.120 * * *$ & $-3.196^{*}$ & $-9.666 * * *$ & $-9.874 * * *$ & & & $-3.501 * * *$ & $-2.96 * *$ \\
\hline & $(-5.08)$ & $(-1.94)$ & $(-3.21)$ & $(-3.58)$ & & & $(-2.98)$ & $(-2.20)$ \\
\hline \multirow[t]{2}{*}{ Lagged home currency misalignment } & & & & & $2.341^{*}$ & $4.206^{* * *}$ & & \\
\hline & & & & & (1.78) & (3.70) & & \\
\hline \multirow[t]{2}{*}{ Lagged foreign currency misalignment } & & & & & $-2.598^{*}$ & $-2.535 * *$ & & \\
\hline & & & & & $(-1.72)$ & $(-2.19)$ & & \\
\hline \multirow[t]{2}{*}{ Domestic real GDP } & $-0.004^{* * *}$ & $-0.001 * *$ & $-0.001 * * *$ & $-0.002 * * *$ & & & $-0.001 * * *$ & $-0.002 *$ \\
\hline & $(-3.88)$ & $(-2.52)$ & $(-2.67)$ & $(-2.66)$ & & & $(-2.69)$ & $(-1.86)$ \\
\hline \multirow[t]{2}{*}{ Foreign real GDP } & $0.001 * * *$ & $0.004^{* * *}$ & $0.002 * *$ & $0.001 * *$ & & & $0.003 * *$ & $0.009 * *$ \\
\hline & $(2.80)$ & (3.23) & (2.50) & (2.01) & & & (2.22) & (2.20) \\
\hline \multirow[t]{2}{*}{ Lagged home real GDP } & & & & & $-0.001^{*}$ & $-0.001 * *$ & & \\
\hline & & & & & $(-1.89)$ & $(-2.32)$ & & \\
\hline \multirow[t]{2}{*}{ Lagged foreign real GDP } & & & & & $0.004^{* *}$ & $0.003 * * *$ & & \\
\hline & & & & & $(2.40)$ & $(2.89)$ & & \\
\hline No of Obsv & 1365 & 1322 & 3354 & 3180 & 9218 & 8915 & 8342 & 8706 \\
\hline$A R(1) p$-value & 0.033 & 0.040 & 0.041 & 0.009 & 0.002 & 0.000 & 0.000 & 0.000 \\
\hline AR(2) p-value & 0.324 & 0.272 & 0.369 & 0.988 & 0.950 & 0.227 & 0.468 & 0.533 \\
\hline Sargan p-value & 0.107 & 0.120 & 0.459 & 0.129 & 0.241 & 0.548 & 0.357 & 0.642 \\
\hline Hansen $p$-value & 0.197 & 0.317 & 0.335 & 0.247 & 0.642 & 0.217 & 0.132 & 0.743 \\
\hline No of groups & 133 & 133 & 210 & 210 & 618 & 618 & 566 & 566 \\
\hline No of Instruments & 16 & 16 & 15 & 15 & 16 & 15 & 15 & 15 \\
\hline
\end{tabular}


Next we divide our baseline sample into subsamples including bilateral trade between emerging markets exclusively (columns 4.1 and 4.2), and bilateral trade involving developed countries only (columns 4.3 and 4.4). Somewhat surprisingly, we find that the misalignments of developed countries' currencies tend to have larger trade impacts than that of emerging markets. ${ }^{15}$

In columns 4.5-4.6, we explore the possibility of "adjustment lags" in the effect of currency misalignment on the trade balance, by delaying the misalignment and GDP variables by one year. Such delays in the adjustment of trade balances could be imputable to trade contracts signed before the change in relative prices (Magee, 1973) as well as "recognition", "decision", "delivery", "replacement" and "production" lags, as identified by Junz and Rhomberg (1973). Again, the results are consistent with our previous findings, suggesting that passed misalignments in home and foreign currencies also impact the current trade balance in a beggar-thy-neighbor fashion.

As mentioned before, current debates on the external effect of currency misalignment are concentrated on China, and so are existing empirical studies on the subject (Eichengreen and Tong, 2011 and Mattoo, Mishra and Subramanian, 2012). The findings presented above suggest that currency undervaluation does have the potential to handicap the other countries' exports; but more importantly, they imply that this feature is not exclusive to the Chinese case. To assess the sensibility of our results to the presence of China in the sample, we replicate our baseline estimates excluding China's bilateral trade data from the analysis, in columns 4.7 and 4.8. Strikingly, our estimated effects display very little sensibility to such an exclusion: $\widehat{\beta_{1}}$ (the internal impact of undervaluation) decreases from 4.9-7.9 to $4.7-7.4$, while $\widehat{\beta_{2}}$ (the external effect of currency undervaluation) is left globally unaffected. Both variables remain highly significant. This suggests that the external effect of the renminbi's undervaluation, which has been the focus of the profession thus far, is actually the "tip of the iceberg".

\section{Conclusion}

This paper aimed at empirically investigating whether currency undervaluation is a beggar-thyneighbor policy. We adopted a new empirical framework that allows us to quantify the external impact of currency undervaluation, while correcting for the shortcomings that go a long way in explaining previous negative findings in the literature. The takeaway message of our assessment is twofold: (i) countries that keep their currencies undervalued do handicap their partners' trade; and (ii) this feature is not exclusive to the Chinese case.

From a policy standpoint, three important implications can be drawn from this analysis. First, our results run counter to the growing "exchange rate pessimism" among economists, i.e., the view that

\footnotetext{
${ }^{15}$ The emerging markets group has been defined by cross-referencing several classifications such as the ones by Standard and Poor's, Columbia University, the FTSE group, The Economist etc. Here also, we drop symmetric pairs of countries, as their impact could be larger in such small subsamples. We have also considered a subsample of trade between developed and emerging markets, with the latter only appearing as "partners"; as well as a subsample of trade between the same group of countries, but with emerging markets being "home countries". Results, available from the author, are globally consistent with the reported findings here.
} 
exchange rate changes have limited impact on trade flows. As stressed by Obstfeld (2002), this is a very old belief that has known several episodes of resurgence, the last of which taking its roots from recent microeconomic evidence (Galindo et al., 2003) as well as recent developments in the structure of global trade (IMF, 2012; Koopman et al., 2012). Our findings suggest that denying to exchange rates any impact on trade flows would be leaving on the sidelines one of the main determinants of the cross-country distribution of trade.

Second, as mentioned before, this paper contributes to the current and intense debate among economists on the causes of global current account imbalances. Our conclusions give support to the "neo-mercantilism view", which puts the emphasis on the substantial undervaluation that seem to exhibit several emerging market currencies.

Finally, our findings caution against recommendations - based on recent empirical evidence - in favor of an active undervaluation strategy to stimulate domestic growth. This paper shows that such selforiented policies are not optimal from an international perspective. More generally, our findings highlight the need for an efficient multilateral surveillance system, if currency undervaluations were proved to be the by-product of deliberate development strategies. But as emphasized by Blanchard and Milesi-Ferretti (2011), proving intent is more difficult in practice.

\section{References}

Aguirre, A., Calderon, C., 2005. Real Exchange Rate Misalignments and Economic Performance. Working Paper 315, Economic Research Division, Central Bank of Chile.

Arellano, M., Bond, S., 1991. Some tests of specification for panel data: Monte Carlo evidence and an application to employment equations. Review of Economic Studies, 58, 277-97.

Bahmani-Oskooee, M., 1985. Devaluation and the J-curve: some evidence from LDCs. The Review of Economics and Statistics, 67, 500-504.

Bahmani-Oskooee, M., Goswami, G. G., 2003. A disaggregated approach to test the J-curve phenomenon: Japan vs. her major trading partners, Journal of Economics and Finance, 27, 102-13.

Bahmani Oskooee, M., Hegerty, W. S., 2010. The J-and S-curves: A Survey of the Recent Literature. Journal of Economic Studies. 37,580-596.

Beck, T., Demirgüç-Kunt, A., Levine, R., 2000. A New Database on Financial Development and Structure. The World Bank Economic Review 14(3), 597-605

Bénassy-Quéré, A., Béreau, S., Mignon V., 2010. On the complementarity of equilibrium exchangerate approaches. Review of International Economics, 18(4), 618-632.

Berman, N., Berthou, A., 2009. Financial Market Imperfections and the Impact of Exchange Rate Movements on Exports. Review of International Economics, 17(1):103-20.

Berman, N., Martin, P., Mayer, T., 2012. How do different exporters react to exchange rate changes? Theory, empirics and aggregate implications. Quarterly Journal of Economics, 127(1), 437-492. 
Bernanke, B., 2005. The Global Saving Glut and the U.S. Current Account Deficit, speech at the Sandridge Lecture, Virginia Association of Economics, Richmond, 10 March, http://www.federalreserve.gov/boarddocs/speeches/2005/200503102/default.htm

Betts, C. M., Devereux, M. D. 2000. Exchange Rate Dynamics in a Model of Pricing-to-Market. Journal of International Economics, 50(1): 215-44.

Blanchard O., Milesi-Ferretti, G., 2011. (Why) Should Current Account Balances Be Reduced?. Staff Discussion Note 11/03. International Monetary Fund.

Blundell, R., Bond, S., 1998. Initial conditions and moment restrictions in dynamic panel data models. Journal of Econometrics, 87, 11-143.

Bussiere, M., 2007. Exchange Rate Pass-Through to Trade Prices: The Role of Non-Linearities and Asymmetries. Working Paper Series 822, European Central Bank

Caballero, R., Farhi, E., Gourinchas, P. O., 2008. An Equilibrium Model of 'Global Imbalances' and Low Interest Rates. American Economic Review, 98, 358-93.

Chen, R., Milesi-Ferretti, G., Tressel, T., 2012. External Imbalances in the Euro Area. IMF Working Paper No. 12/236.

Chinn, M., Prasad, E., 2003. Medium-Term Determinants of Current Accounts in Industrial and Developing Countries: An Empirical Exploration. Journal of International Economics, 59(1), 47-76.

Chit, M., Rizov, M., Willenbockel, D., 2008. Exchange rate volatility and exports: new empirical evidence from the emerging East Asian Economies. Middlesex University Economics and Statistics Discussion Paper No. 127.

Combes, J.-L. Guillaumont, P., 2002. Commodity price volatility, vulnerability and development. Development Policy Review, 20(1), 25-39.

Corsetti, G., Pesenti, P., 2001. Welfare and Macroeconomic Interdependence. Quarterly Journal of Economics.

Coudert, V. Couharde, C., 2009. Currency Misalignments and Exchange Rate Regimes in Emerging and Developing Countries. Review of International Economics, 17, 121-36.

Coudert, V., Couharde, C., Mignon, V., 2012. On currency misalignments within the euro area. EconomiX Working Papers 2012-30, University of Paris West.

Dekle, R. H., Ryoo, H., 2007. Exchange rate fluctuations, financing constraints, hedging, and exports: Evidence from firm level data. Journal of International Financial Markets, Institutions and Money, $17,437-451$

Delatte, A., López-Villavicencio, A., 2012. Asymmetric exchange rate pass-through: Evidence from major countries. Journal of Macroeconomics, 34(3), 833-844.

Dooley, P. M., Folkerts-Landau, D., Garber, P., 2003. An essay on the revived Bretton Woods system. NBER Working Papers 9971.

Eichengreen, B., 2007. Comment on Cheung, Chinn and Fujii, "The Overvaluation of Renminbi Undervaluation"”, Journal of International Money and Finance, 26 (5), 786-787.

Eichengreen, B. Tong, H., 2011. The External Impact of China's Exchange Rate Policy: Evidence from Firm Level Data. IMF Working Paper, 155.

Fang, W., Lai, Y., Miller, S., 2006. Export Promotion through Exchange Rate Changes: Exchange Rate Depreciation or Stabilization? Southern Economic Journal 72(3): 611-626. 
Feenstra, R.C., Wen, H., Wing, T.W., Shunli, Y., 1998. The US-China bilateral Trade balance: its size and determinants. NBER Working Papers 6598.

Forbes, K., 2002. How Do Large Depreciations Affect Firm Performance, NBER Working Paper No. 9095

Francois, J., 2010. Deconstructing Sino-US Codependence: Revaluation, Tariffs, Exports and Jobs," in Simon Evenett, ed., The US-Sino Currency Dispute: New Insights from Economics Politics and Law, London, CEPR and VoxEU.

Froot, K. A., Rogoff, K., 1995. Perspectives on PPP and long-run real exchange rates. in: G. M. Grossman \& K. Rogoff (ed.), Handbook of International Economics(1), 1647-1688.

Gala, P., Rocha, M., 2009. Real exchange rates, domestic and foreign savings: the missing link. Anais do XXXVII Encontro Nacional de Economia da ANPEC, Foz do Iguaçu.

Galindo, A., Panizza, U., Schiantarelli, F., 2003. Debt composition and balance sheet effects of currency depreciation: A summary of the micro evidence. Emerging Markets Review 4 (4): 330-39.

Gust, C., Leduc, S., Vigfusson, R. J., 2006. Trade Integration, Competition, and the Decline in Exchange-Rate Pass-Through. International Finance Discussion Papers 864.

Helkie, W.L., Hooper, P., 1987. The U.S. External Deficit in the 1980s. International Finance Discussion Paper No. 304, Board of Governors, Federal Reserve System.

Hsieh, C., Ossa, R., 2011. A Global View of Productivity Growth in China. NBER Working Paper, 16778.

Huang, Y., Tao, K., 2010. Causes and Remedies of China's Current Account Surpluses. CCER Working Paper 2010002. China Center for Economic Research, Peking University, Beijing.

Imbs, J., Mejean, I., 2008. Elasticity Optimism. mimeo HEC-Lausanne.

IMF, 2005. Global Imbalances a Saving and Investment Perspective. Chapter 2 World Economic Outlook.

IMF, 2012. Changing Patterns of Global Trade. Departmental Paper No. 12/01.

Junz, H. B., Rhomberg, R. R., 1973. Price-competitiveness in export trade among industrial countries. American Economic Review, 63(2), 412-18.

Koopman, R., Wang, Z., Wei, S. J., 2012. How much of Chinese exports is really made in China. Journal of Development Economics, forthcoming.

Krugman, P., Baldwin, R., 1987. The Persistence of the US Trade Deficit. Brookings Papers on Economic Activity, 1, 1-43

Krugman, P., 2010. Chinese New Year. New York Times. Available at www.nytimes.com.

Levy Yeyati, E., Sturzenegger, F., 2007. Fear of Appreciation. World Bank Policy Research Working Paper 4387.

MacDonald, R., 1997. What Determines the Real Exchange Rate? The Long and the Short of It. IMF working paper 97/21.

Magee, S. P., 1973. Currency contracts, pass through and devaluation. Brooking Papers on Economic Activity, 1,303-25.

Marwah, K., Klein, L. R., 1996. Estimation of J-curve: United States and Canada, Canadian Journal of Economics, 29, 523-39.

Mattoo, A., Mishra., P., Subramanian, A., 2012. Spillover Effects of Exchange Rates: A Study of the Renminbi. IMF Working Papers 12/88.

Mbaye, S., 2012. Currency Undervaluation and Growth: Is there a Productivity Channel?. International Economics / Economie Internationale forthcoming 
McKinnon, R., 2010. Why Exchange Rate Changes Will Not Correct Global Trade Imbalances. SIEPR policy brief. Stanford Institute for Economic Policy Research.

Mendoza, E. G., Quadrini, V., Ríos-Rull, J.-V., 2009. Financial Integration, Financial Development, and Global Imbalances. Journal of Political Economy, 117(3), 371-416.

Montiel, P., Serven, L., 2008. Real Exchange Rates, Saving and Growth: Is There a Link?" World Bank Policy Research, Working Paper No. 4636.

Nouira, R., Sekkat, K., 2012. Desperately seeking the positive impact of undervaluation on growth. Journal of Macroeconomics doi:10.1016/j.jmacro.2011.12.002.

Obstfeld, M., Rogoff, K., 1995. Exchange Rate Dynamics Redux. Journal of Political Economy 103, (3), 624-660.

Obstfeld, M., Rogoff, K., 1996. Foundations of International Macroeconomics. MIT Press.

Obstfeld, M., 2002. Exchange Rates and Adjustment: Perspectives from the New Open Economy Macroeconomics. NBER Working Paper No. 9118.

Pesaran, M., Shin, Y. \& Smith, R., P., 1999. Pooled Mean Group Estimation of Dynamic Heterogeneous Panels. Journal of the American Statistical Association, 94(446), 621-634.

Rodrik, D., 2008. The Real Exchange Rate and Economic Growth. Brookings Papers on Economic Activity, 2, 365-412.

Roodman, D., 2006. How to do xtabond2: An introduction to "Difference" and "System" GMM in Stata. Working Paper 103, The Center for Global Development.

Roodman, D., 2008. A note on the theme of too many instruments. Working Paper 125, The Center for Global Development.

Rose, A., Yellen, J., 1989: Is There a J-Curve?. Journal of Monetary Economics, 24, 53-68.

Subramanian, A., 2010. New PPP-Based Estimates of Renminbi Undervaluation and Policy Implications. Policy Brief PB10-18, Peterson Institute for International Economics.

Stein, J., 1994. Estimating Equilibrium Exchange Rates: the Naturel Real Exchange Rate of the US dollar and Determinants of Capital Flows, in Estimating Equilibrium Exchange Rate.

Tille, C., 2000. 'Beggar-thy-neighbor' or 'beggar-thyself'? The income effect of exchange rate fluctuations. Federal Reserve Bank of New York Working paper.

Westerlund, J., Persyn, D., 2008. Error-Correction-Based Cointegration Tests For Panel Data. The Stata Journal, 8 (2), 232-241.

Wilson, P., 2001. Exchange rates and the trade balance for dynamic Asian economies: does the J-curve exist for Singapore, Malaysia and Korea?, Open Economies Review, 12, 389-413. 


\section{Appendixes}

\section{Table A1: List of countries}

\section{Developed countries}

Australia, Austria, Belgium, Canada, Cyprus, Denmark, Finland, France, Germany, Greece, Hong Kong, Ireland, Iceland, Israel, Italy, Japan, Luxembourg, Malta, Netherlands, Norway, New Zealand, Portugal, Sweden, Switzerland, Spain, Trinidad and Tobago, United States, United Kingdom,

\section{Emerging markets}

Argentina, Bulgaria, Brazil, Chile, China, Colombia, Cape Verde, Czech Republic, Ecuador, Egypt, Arab Rep., Estonia, Croatia, Hungary, Indonesia, India, Jamaica, Jordan, Korea Rep., Lithuania, Mexico, Mauritius, Malaysia, Peru, Philippines, Poland, Romania, Russian Federation, Singapore, Slovak Republic, Slovenia, Thailand, Tunisia, Turkey, Uruguay, South Africa

Table A2: Unit root and cointegration tests

Unit root tests

\begin{tabular}{|c|c|c|c|c|c|c|c|c|c|c|}
\hline & \multicolumn{2}{|c|}{1.1} & \multicolumn{2}{|c|}{1.2} & \multicolumn{2}{|c|}{1.3} & \multicolumn{2}{|c|}{1.4} & \multicolumn{2}{|c|}{1.5} \\
\hline & $\begin{array}{l}\text { Maddala } \\
\text { and Wu } \\
\text { (1999) }\end{array}$ & $\begin{array}{c}\text { Pesaran } \\
\text { (2007) } \\
\text { CIPS }\end{array}$ & $\begin{array}{l}\text { Maddala } \\
\text { and Wu } \\
\text { (1999) }\end{array}$ & $\begin{array}{c}\text { Pesaran } \\
(2007) \\
\text { CIPS }\end{array}$ & $\begin{array}{l}\text { Maddala } \\
\text { and Wu } \\
\text { (1999) }\end{array}$ & $\begin{array}{c}\text { Pesaran } \\
\text { (2007) } \\
\text { CIPS }\end{array}$ & $\begin{array}{c}\text { Maddala } \\
\text { and Wu } \\
(1999)\end{array}$ & $\begin{array}{c}\text { Pesaran } \\
(2007) \\
\text { CIPS }\end{array}$ & $\begin{array}{l}\text { Maddala } \\
\text { and Wu } \\
\text { (1999) }\end{array}$ & $\begin{array}{c}\text { Pesaran } \\
\text { (2007) } \\
\text { CIPS }\end{array}$ \\
\hline PPP RER & 0.987 & 0.403 & 0.987 & 0.403 & & & & & & \\
\hline $\mathrm{RGDPCH}$ & 0.867 & 0.784 & 0.867 & 0.784 & & & & & 0.867 & 0.784 \\
\hline NFA & & & 0.808 & 0.999 & 0.808 & 0.999 & 0.808 & 0.999 & & \\
\hline REER & & & & & 0.731 & 0.254 & 0.731 & 0.254 & & \\
\hline BALASSA & & & & & 0.567 & 0.941 & 0.567 & 0.941 & & \\
\hline TRADE & & & & & & & 0.985 & 0.999 & & \\
\hline G & & & & & & & 0.268 & 0.802 & & \\
\hline TOT & & & & & & & 0.765 & 0.564 & & \\
\hline TB to GDP ratio & & & & & & & & & 0.02 & 0.01 \\
\hline MISPPP1 & & & & & & & & & 0.00 & 0.00 \\
\hline MISPPP2 & & & & & & & & & 0.01 & 0.00 \\
\hline MISBEER1 & & & & & & & & & 0.00 & 0.00 \\
\hline MISBEER2 & & & & & & & & & 0.00 & 0.00 \\
\hline$\triangle \mathrm{RGDCH}$ & & & & & & & & & 0.01 & 0.00 \\
\hline
\end{tabular}

Panel cointegration tests

\begin{tabular}{l|l|l|l|l|l|}
\hline Kao test & 0.00 & 0.00 & 0.00 & 0.06 \\
Group Gt & 0.00 & 0.00 & 0.00 & 0.00 \\
Group Ga & 0.02 & 0.04 & 0.01 & 0.02 \\
Panel Pt & 0.00 & 0.00 & 0.00 & 0.00 \\
Panel Pa & 0.01 & 0.00 & 0.00 & 0.00 & \\
\hline
\end{tabular}

Note: Numbers reported here are p-values. All specifications include a maximum of two lags. For each cointegration test, the model is composed of variables for which the unit root test results are displayed in the upper side of the corresponding column. Group Gt, Group Ga, Panel Pt, and Panel Pa are Westerlund and Persyn (2008)'s cointegration tests. For all these tests, the null hypothesis is the absence of cointegration. For the unit root tests, the null hypothesis is the presence of unit root. 
Table A3: Enhanced-PPP-based long-run RER equation

\begin{tabular}{crc}
\hline & PPP GDP & Net foreign \\
& per capita & assets \\
Equation 5 & $-0.31 * * *$ & \\
& $(-44.47)$ & \\
Equation 6 & $-0.27 * * *$ & $-0.16^{* * *}$ \\
& $(-5.07)$ & $(-4.01)$ \\
\hline Note: *significant at $10 \% * *$ significant at $5 \% * * *$ significant at $1 \%$
\end{tabular}

Table A4: BEER-based long-run REER equation

\begin{tabular}{cccccc}
\hline & $\begin{array}{c}\text { Balassa- } \\
\text { Samuelson }\end{array}$ & $\begin{array}{c}\text { Net foreign } \\
\text { assets }\end{array}$ & Terms of trade & $\begin{array}{c}\text { Public } \\
\text { expenditures }\end{array}$ & Trade openess \\
Equation 9 & $\begin{array}{c}0.56^{* * *} \\
(8.30)\end{array}$ & $\begin{array}{l}0.09 * * * \\
(6.12)\end{array}$ & & & \\
& $0.17^{* * *}$ & $0.09 * * *$ & $0.22^{* * *}$ & $0.17^{* * *}$ & $-0.16^{* * *}$ \\
Equation 10 & $(4.13)$ & $(9.96)$ & $(6.74)$ & $(8.13)$ & $(-5.55)$ \\
\hline
\end{tabular}

Note: *significant at $10 \% * *$ significant at $5 \% * * *$ significant at $1 \%$. Robust t-statistics in parentheses.

Table A5: Correlations between misalignment indexes

\begin{tabular}{|c|c|c|c|}
\hline & Misppp $^{1}$ & Misppp ${ }^{2}$ & Misbeer $^{1}$ \\
\hline Misppp $^{1}$ & 1 & & \\
\hline Misppp $^{2}$ & $0.84 * * *$ & 1 & \\
\hline Misbeer $^{1}$ & $0.42 * * *$ & $0.40 * * *$ & 1 \\
\hline Misbeer $^{2}$ & $0.34^{* * *}$ & $0.38^{* * *}$ & $0.86^{* * *}$ \\
\hline
\end{tabular}

